\title{
Desaparecidos vivos e filiação feminina em Júlia, de Bernardo Kucinski
}

\author{
Missing alive and feminine filiation in Júlia, by Bernardo Kucinski
}

Marianna SCARAMUCCI*

Università degli Studi di Milano

Resumo: O artigo propõe uma análise da tematização da tragédia das crianças sequestradas pelo regime militar brasileiro no romance Júlia. Nos campos conflagrados do Senhor, de Bernardo Kucinski (2020). Constatando primeiro a dimensão do silenciamento que envolve este trauma no Brasil de hoje (Reina), o artigo passa a reflexionar sobre seu escasso tratamento literário (Figueiredo; Gill da Cruz), para propor uma análise das figuras dos “desaparecidos vivos" (Basile) no romance e da complexidade com a qual Kucinski traz à tona o problema de uma violência transgeracional com base na filiação feminina fraturada, e a possibilidade de uma recomposição identitária pela via materna.

PALAVRAS-CHAVE: crianças sequestradas. Ditadura militar. Desaparecidos; Filiação feminina; Bernardo Kucinski.

\begin{abstract}
The article proposes an analysis of the tragedy of children kidnapped by the Brazilian military regime in the novel Júlia. Nos campos conflagrados do Senhor, by Bernardo Kucinski (2020). Observing, at first, the dimension of the silence that involves this trauma in today's Brazil (Reina), the article reflects on its limited literary treatment (Figueiredo; Gill da Cruz), to propose an analysis of the "missing alive" (Basile) in Kucinski's novel and the complexity with which the author brings to light the problem of transgenerational violence based on fractured feminine filiation, and the possibility of an identity through the maternal line.
\end{abstract}

\footnotetext{
* Doutora em Estudos linguísticos, literários e interculturais em âmbito europeu e extra-europeu e pesquisadora em Literatura Portuguesa e Brasileira pela Università degli Studi di Milano (Itália). E-mail: marianna.scaramucci@unimi.it
}

Revista Moara, n. 59, ago-dez 2021 ISSN: 0104-0944 
KEYWORDS: kidnapped children. Military dictatorship. Desaparecidos; Female filiation; Bernardo Kucinski.

\section{1 "O segredo dentro do segredo"}

Ao introduzir o ensaio Cativeiro sem fim. As histórias dos bebês, crianças e adolescentes sequestrados pela ditadura militar no Brasil - publicado em 2019 pelo jornalista Eduardo Reina - o Diretor executivo do Instituto Vladimir Herzog, Rogério Sottili, escreve: "apesar de ter tido uma das mais violentas e vigorosas ditaduras do continente, com milhares de mortos e desaparecidos, o Brasil tem em seus registros oficiais um único caso de criança sequestrada por motivos políticos durante o regime militar" (Reina, 2019).

De fato, no caso de crimes de sequestro de bebês, crianças e adolescentes na época ditatorial, a "vocação brasileira para a amnésia" parece se intensificar, desencadeando mecanismos de negação e remoção se possível ainda mais perversos. Um silêncio ensurdecedor envolve essa forma de violação dos direitos humanos que, pelo contrário, foi amplamente denunciada, documentada e elaborada na pós-ditadura de países vizinhos como Argentina, Chile e Uruguai (Reina, 2019).

Como é sabido, a resposta à pergunta sobre "o que resta da ditadura", no Brasil, é muito menos óbvia do que complexa, visto que, a partir da inevitável comparação com as vicissitudes dos países do Cone Sul latino-americano que experimentaram os regimes militares na segunda metade do séc. XX, emerge uma dimensão de excecionalidade que envolve tanto o período ditatorial como o da pós-ditadura. É a exceção detectada por Edson Teles e Vladimir Safatle em 2015, quando, ao introduzirem a hoje célebre coletânea $O$ que resta da ditadura? salientavam que a "exceção" da ditadura brasileira é algo que não se mede por números, "mas através das marcas que ela deixa no presente, ou seja, através daquilo que ela deixará para frente" (2015, p. 10). Se, por um lado, o discurso da "página virada" faz com que o estereótipo da ditabranda continue a funcionar dentro do imaginário coletivo, por outro, a falta de umas políticas efetivas da memória produziu um efeito de perpetração da violência no tempo que tem consequências de extrema gravidade.

Como escrevem Edson Teles e Vladimir Safatle: 
Quando estudos demonstram que, ao contrário do que aconteceu em outros países da América Latina, as práticas de tortura em prisões brasileiras aumentaram em relação aos casos de tortura na ditadura militar; quando vemos o Brasil como o único país sul-americano onde torturadores nunca foram julgados, onde não houve justiça de transição, onde o Exército não fez um mea culpa de seus pendores golpistas; quando ouvimos sistematicamente oficiais na ativa e na reserva fazerem elogios inacreditáveis à ditadura militar; quando lembramos que 25 anos depois do fim da ditadura convivemos com o ocultamento de cadáveres daqueles que morreram nas mãos das Forças Armadas; então começamos a ver, de maneira um pouco mais clara, o que significa exatamente "violência" (2015, p. 10).

E a medida desta violência perpétua parece ser o silêncio, ou os múltiplos silêncios, em relação aos corpos e às identidades das vítimas, aos crimes e aos seus autores, mas também aos documentos, visto que até nos governos democráticos de Fernando Henrique Cardoso e de Luiz Inácio Lula da Silva confirmaram-se disposições que, na sustância, possibilitam o "sigilo eterno de certos documentos" (Silveira-Bauer, 2011, p. 373). Se enfrentarmos esta realidade, então, a equação inverte-se: quanto mais silêncio, mais violência. Assim, o estereótipo da ditabranda se desmancha, deixando espaço para outra verdade, a que "a ditadura brasileira foi a ditadura mais violenta que o ciclo negro latino-americano conheceu" (Teles; Safatle, 2015, p. 10).

Como num conjunto de caixas chinesas, dentro deste mecanismo de histórias não contadas, os casos de menores sequestrados pela ditadura militar brasileira aparecem como um "segredo dentro do segredo". Esta é a definição que Eduardo Reina (2019) propõe para descrever o esquecimento e a desmemória que envolvem estes sucessos. Já a partir do trabalho de pesquisa feito para a publicação, em 2016, da obra ficcional Depois da Rua Tutóia, o jornalista passou a questionar a incongruência entre a quantidade de casos denunciados no contexto argentino e a aparente inexistência deste tipo de crime no caso brasileiro. Em entrevista pela Univesp TV, em 2016, Reina já salientava a quantidade de casos de crianças sequestradas denunciados - e em parte resolvidos - na Argentina, ao passo que no Brasil só se tinha conhecimento de um caso, enquanto 
(apenas) outros 8 casos estavam em tramitação ${ }^{1}$. Isso seria o resultado não tanto de uma "inexistência" deste tipo de crime no Brasil, quanto de um enorme atraso nas pesquisas, nas denúncias e nas investigações.

De fato, só recentemente é que começou a vir à tona um número maior de crimes de "sequestro e apropriação de bebês, crianças e adolescentes por pessoas ligadas às Forças Armadas":

\begin{abstract}
Há casos de bebês que foram levados logo ao nascer, desapareceram ou foram entregues a instituições como orfanatos e acabaram adotados de forma irregular por famílias. Ou então as vítimas são crianças ou adolescentes levados para quartéis em outros estados, onde passaram por uma espécie de lavagem cerebral [...] Há ainda casos de bebês [...] que foram apropriados e registrados como filhos legítimos de militares. Houve ainda a simples apropriação de crianças sob a anuência dos militares, e hoje tais vítimas estão desaparecidas (Reina, 2019).
\end{abstract}

No seu trabalho de 2019 sobre o tema, Reina pesquisa e expõe um total de 19 casos que remetem a este tipo de crimes, muitos dos quais (11) relacionados diretamente à repressão no Araguaia. É importante destacar como este dato histórico venha a nos confirmar, mais uma vez, não só um dúplice esquecimento, mas também um dúplice, triste, papel "pioneiro" do Brasil no caso das práticas repressivas. Como notava Roberto Vecchi ao analisar a "espectrografia" da ideologia repressiva que o caso de Araguaia nos fornece, embora o desaparecimento tenha sido genericamente identificado quase como uma "invenção argentina", devemos lembrar que "deste dispositivo refinado de violência pública, o Brasil historicamente foi, no subcontinente, um dos primeiros laboratórios que elaboraram suas tecnologias do horror genocidário" (Vecchi, 2015, p. 152). E, reconhecia Vecchi, o caso mais representativo é justamente o da repressão da guerrilha no Araguaia “que o tornou hoje, não é só mais uma página em branco da história (ainda largamente por escrever) da ditadura militar no Brasil, mas, em simultâneo, o mais espectral" (Vecchi, 2015, p. 152). Da mesma forma, Reina confirma que:

\footnotetext{
${ }^{1} \mathrm{O}$ dossier Direito à memória e à verdade: histórias de meninos e meninas marcados pela ditadura, publicado em 2009 pela Secretaria Especial dos Direitos Humanos da Presidência da República, ainda indicava apenas "4 crianças provavelmente sequestradas" na ditadura (Secretaria Especial dos Direitos Humanos, 2009, p. 101).
} 
as ações das forças militares brasileiras durante a ditadura - incluindo os crimes de sequestro e apropriação de crianças - serviram de laboratório, uma espécie de operação assistida. E posteriormente formaram a base para atividades semelhantes e cruéis desempenhadas pela repressão argentina, chilena, uruguaia, paraguaia e de outros países do Cone Sul naqueles anos de chumbo (Reina 2019).

Nesta perspectiva, a prática do desaparecimento, do sequestro e da apropriação de crianças assume outra dimensão: por um lado ela vem a compor mais uma peça daquela "espectrografia" que vê a ideologia repressiva brasileira se fundar em lacunas, vazios, silenciamentos, e por outro volta a confirmar como o caso brasileiro cumpra um papel precursor na implementação de tecnologias do terror que serão depois aplicadas em outros países. Não por acaso, Reina repara em que os sequestros de crianças formaram parte de uma precisa "lógica de guerra", com "o objetivo de difundir o terror entre a população; vingar-se das famílias; interrogar às crianças; quebrar o silêncio de seus pais, torturando seus filhos; educar as crianças com uma ideologia contrária à dos seus pais e a apropriação dessas crianças. Elas se transformaram num verdadeiro butim de guerra" (Reina, 2019).

A apropriação de menores pelas forças repressivas pode ser considerada então como uma forma de violência que, no laboratório-Brasil, teve o caráter de uma tecnologia do terror inserida numa lógica de guerra. Mas são os seus efeitos no presente os que nos dão a dimensão desta violência, pois ela se desdobra especialmente no plano temporal. $\mathrm{O}$ que estas crianças experimentaram foi o início de um "cativeiro sem fim", para retomar o título da obra de Reina, pois elas foram despojadas de uns inúmeros signos que, ao nível semiótico e psicológico, constituem a nossa identidade: foram privadas dos nomes, das datas e lugares de nascimento, das suas genealogias. Sua história e sua identidade foram roubadas, jogadas para sempre na mentira e no segredo, sem possibilidade de reconstruílas na sua inteireza. Como explica Reina na Introdução: "parte dos que sobreviveram ainda procuram por seus pais biológicos, numa busca surda e muda, alheia à sociedade e à história” (Reina, 2019).

Portanto, esse "mal de Alzheimer nacional” que Bernardo Kucinski diagnosticava ao país em relação aos crimes da ditadura, e particularmente ao desaparecimento, parece 
atingir de forma muito grave as crianças vítimas da violência ditatorial. Com efeito, o mecanismo da privatização do luto e da perda - devido à falta de um compromisso público pleno com a justiça e a verdade e à dificuldade de acesso a arquivos e documentos - faz com que a busca de informações e a tarefa de recuperação de umas identidades despedaçadas fique principalmente a cargo das vítimas. Além disso, ao abandono das vítimas sobrepõe-se a violência do silenciamento das suas vicissitudes. Quando, em maio de 2013, a Comissão da Verdade do Estado de São Paulo "Rubens Paiva” organiza o ciclo de audiências "Verdade e Infância Roubada", o seu propósito é justamente o de ouvir os testemunhos de "filhos de presos políticos, perseguidos e desaparecidos da ditadura [...] cujas histórias ainda não haviam sido contadas" (p. 11). O resultado desse ciclo foi o livro Infância Roubada (2014), que recolhe mais de 40 depoimentos dos que compareceram nas sessões públicas e dos que escolheram responder a entrevistas ou deixar testemunho escrito, um livro pautado "no cumprimento de um compromisso da Democracia Brasileira com uma geração pouco conhecida, formada por crianças e adolescentes filhos de perseguidos políticos e desaparecidos durante o período autoritário, de 1964 a 1985” (p. 9).

\section{0 campo literário: narrativas de filiação e sobre filiação}

Essa "geração" brasileira continua sendo, até hoje, pouco conhecida, especialmente se a compararmos com o panorama argentino, onde a atuação das Abuelas de Plaza de Mayo e das agrupações de filhos e filhas de desaparecidos e presos políticos teve um peso enorme na luta pela verdade e a justiça, e na construção pública de umas efetivas políticas da memória. Neste âmbito, também a produção artística e literária desempenha um papel imprescindível na reelaboração transgeracional dos traumas e na recomposição, sempre extremamente complexa, dos pedaços dispersos de centenas de biografias. As narrativas de hijos e hijas, na Argentina, vieram a compor um imenso campo literário - que trabalha a parir do testemunho, da ficção ou da autoficção ${ }^{2}$ - ao passo que, no caso do Brasil, resulta mais difícil delinear um campo literário amplo em

\footnotetext{
${ }^{2}$ Entre os muitos estudos sobre a questão da reelaboração da identidade dos filhos, assinalamos o de Leonor Arfuch, "Narrativas en el país de la infancia". Alea, Estudos Neolatinos, vol. 18, 2016, p. 544-560, e o estudo de Teresa Basile, Infancias. La narrativa argentina de HIJOS, Eduvim, 2019.
}

Revista Moara, n. 59, ago-dez 2021 ISSN: 0104-0944 
que a geração de filhos e filhas diretamente afetada pelo trauma do exílio, do desaparecimento e da repressão, trabalhe narrativamente o tema e o próprio trauma.

Uma revisão completa da bibliografia, neste sentido, excederia os limites e os objetivos do nosso trabalho, ainda assim, é possível tentar uma organização mínima, que ajude a delimitar o nosso campo, para colocar com mais precisão a posição que o romance de Bernardo Kucinski, Júlia, ocupa no panorama da representação narrativa do trauma dos filhos de presos e desaparecidos políticos. Vou tomar como referência, para tal propósito, o trabalho de Eurídice Figueiredo, A literatura como arquivo da ditadura brasileira, e o recentíssimo trabalho de Lua Gill da Cruz, Pretéritos futuros: ditadura militar na literatura do século XXI.

Entre as obras que poderíamos rotular - ainda que em via hipotética - como narrativas diretas da memória de filhos e filhas ou "narrativas de filiação", encontramos o romance publicado em 2015 por Marcelo Rubens Paiva, Ainda estou aqui, onde a narrativa lida com o interrogativo que angustiou, por décadas, o autor-narrador: "Quem era meu pai? Por que a tortura foi tão violenta? Falo de décadas de mistério. O que aconteceu, como?" (Paiva, 2015, p. 217). O texto embrenha-se nos paradoxos da memória, na dilacerante oposição entre a luta pela memória - luta integérrima de uma mulher, Eunice Paiva, e da sua família, pela justiça e pela verdade - e o esquecimento, o de um país inteiro e o de uma mente, a da Eunice, esvaziada pelo Alzheimer. Um romance de testemunho e memória, em que o filho, escritor e narrador, lida com a ausência de um pai desaparecido, com essa morte "que não tem fim".

Também no caso dos romances Mar Azul, de Paloma Vidal (2012) e A resistência, de Julián Fuks (2015), poderíamos talvez falar em "narrativas de filiação" e, mais especificamente, como assinala Eurídice Figueiredo (2017, p. 112), de narrativas dos “filhos do exílio". Os dois autores são filhos de exilados argentinos no Brasil, e suas narrativas tematizam e reelaboram, de formas diferentes, as sequelas do exílio por motivos políticos desde o ponto de vista das relações pais-filhos. Além disso, o romance de Fuks traz à tona, em constante diálogo com a experiência argentina, o problema da filiação e da herança, no caso do irmão adoptado pela família do autor, numa procura dolorosa pela identidade que se cruza com a luta, em Buenos Aires, das Abuelas de Plaza de Mayo. 
Na proposta de Lua Gill da Cruz, os romances de Paloma Vidal e Julián Fuks pertenceriam àquela que a pesquisadora denomina "produção transgeracional do século XXI", dentro da qual cabem também obras como A chave de casa, de Tatiana Salem Levy (2007), Antes do passado, de Liniane Haag Brum (2012), e Noite dentro da noite, de Joca Reiners Terron (2017). Em todos estes caso temos "autores filhos, sobrinhos ou familiares de perseguidos, exilados, mortos e desaparecidos que constroem essa memória e narrativa a partir de uma transmissão familiar" (Gill da Cruz, 2021, p. 58). Se Tatiana Salem Levy constrói uma narrativa que lida com diversas camadas da herança familiar, na qual se cruzam a diáspora e o exílio nos anos da ditadura militar, época em que a autora nasceu, Joca Reiners Terron evoca a memória da infância sob o regime militar, numa escrita altamente transfigurada, na qual o espaço autobiográfico se funde com a construção ficcional. Por outro lado, Liniane Haag Brum, compõe um texto de teor testemunhal a partir de uma experiência biográfica relacionada à guerrilha do Araguaia: a autora, sobrinha do militante Cilon Cunha Brum, morto e desaparecido na guerrilha, quebra o silêncio, familiar e histórico, que pairava sobre as vicissitudes do tio, empreendendo, e narrativizando, uma busca que se concluiu com a publicação do livro (Figueiredo, 2017, p. 91, 92).

É preciso notarmos, para o nosso objetivo, que dentro destes romances de transmissão familiar e transgeracional - que chamamos romances de filiação - o tema das crianças sequestradas não está nunca presente, nem temos autores-testemunhas que trabalhem, a través da ficção, esse específico trauma vivido em primeira pessoa. A este propósito, na sua exaustiva revisão bibliográfica, Gill da Cruz faz referência a um grupo de romances que sim "tematizam filhos adotados e/ou roubados, durante a ditadura" (2021, p. 60). Entre eles aparecem, além dos trabalhos aqui mencionados de Eduardo Reina, também Palavras cruzadas, de Guiomar de Grammont (2015), e Júlia, de Bernardo Kucinski. Como faz notar Eurídice Figueiredo, tanto o romance de Grammont como o de Reina, Depois da rua Tutóia (2016), "tematizam algo de que não se fala, o desaparecimento e o sequestro de bebês na ditadura brasileira" (Figueiredo, 2017, p. 93). Os dois autores, nascidos nos anos 1960, se encarregam portanto de transmitir, ao que parece pela primeira vez, essa história silenciada, mesmo sem que ela se relacione diretamente com suas experiências biográficas. Poderíamos então pensar nestes romances como "narrativas sobre filiação", que, no específico, se relacionam a-biograficamente, 
com a transmissão da memória de uma filiação fraturada na raiz pelo crime de sequestro das crianças.

O mesmo acontece no caso de Bernardo Kucinski, que em 2020 publica Júlia. Nos campos conflagrados do Senhor. Ao encerrar o livro o autor comenta:

\footnotetext{
A primeira versão desta novela foi completada em novembro de 2011. Passou por muitas mudanças até chegar a esta versão, em novembro de 2019. Embora os cenários em que se desenvolve a história sejam calcados em acontecimentos, a trama e seus personagens são puras invenções (Kucinski, 2020).
}

Kucinski constrói uma ficção que se funda numa base factual, uma base que não é autobiográfica, embora, como é sabido, o autor tenha relação biográfica com a militância contra o regime e com a catástrofe do desaparecimento na ditadura, e também, na pós-ditadura, com a luta de familiares de desaparecidos políticos, tendo desempenhado um papel de destaque na "restituição" literária desse trauma e na atuação pública, como familiar, jornalista e escritor, pela verdade e a justiça no Brasil. A partir desta posição o autor dá vida a esta obra ficcional, um romance sobre filiação que aborda esse espaço silenciado pela política e pouco trabalhado pela literatura brasileira, que ainda não tem sido objeto de uma narrativa de filiação direta: esse segredo dentro do segredo que são as infâncias roubadas.

\section{Os "desaparecidos vivos" em Júlia}

É preciso destacar que o romance de Kucinski lida com dois níveis diferentes desta filiação fraturada, ou, poderíamos dizer, com dois níveis da "busca", relativos tanto ao desaparecimento como à subtração de crianças. No primeiro plano há a história da protagonista, Júlia, jovem mulher que ao descobrir-se filha adotiva, empreende uma busca para conhecer a identidade da mãe, e reconstruir, ao mesmo tempo, sua própria identidade. Júlia foi adotada pelo seu próprio pai, e portanto não representa as vítimas de sequestros, mas as vítimas do desaparecimento forçado de um genitor. Porém, no painel de fundo do romance, paira o fantasma desses bebês, filhos de prisioneiras políticas, que foram sequestrados pelo regime militar e ilegalmente entregues a outras famílias.

Revista Moara, n. 59, ago-dez 2021 ISSN: 0104-0944 
O romance divide claramente, e graficamente, as duas épocas em que se desenrolam os fatos. Nos capítulos relativos aos anos 1960-70, acompanhamos as vicissitudes de Durval, o pai de Júlia, e da mãe biológica que ela nunca conheceu, Maria do Rosário. Chegada de bebê e crescida no orfanato de São Vicente de Paula, em Jacareí, Rosário trabalha como enfermeira na casa maternal do mesmo orfanato, e se envolve na atividade política junto à Juventude Universitária Católica. Nesse contexto conhece Durval, professor empenhado na defesa dos estudantes perseguidos pelo regime. Da relação entre os dois nascerá Júlia. Mas Rosário, no orfanato, faz-se também testemunha do crime de roubo de crianças - levado a cabo pela cumplicidade entre a Igreja conivente com o regime, o aparato burocrático e os militares - e empreende uma atividade de investigação clandestina e de denúncia pela qual será presa e desaparecida.

Se nos capítulos que acompanham a descoberta e a busca de Júlia - trinta anos mais tarde - o que prevalece são os vazios, as lacunas e as perguntas sobre um passado até aquele momento recalcado e submerso na mentira e no segredo, nos capítulos dedicados à época ditatorial, o narrador se encarrega de preencher vazios e silêncios da história pública e familiar, numa ficção que restitui o que foi subtraído à história do país e à biografia da personagem.

É aqui que o romance de Kucinski deixa aparecer na narrativa a tragédia dessas crianças que, como sugere Teresa Basile se referindo ao contesto argentino, são o paradigma original do que em tempos recentes se veio a definir como o "desaparecido vivo". Na acepção que Basile atribui a este termo, a ideia do "desaparecido vivo" serve como contraponto à figura do "detido-desaparecido", cujo destino tem sido quase sempre o assassínio: "La clave de esta figura radica en la apropiación por parte de la maquinaria del terrorismo de Estado, que quitaba todos los derechos a los niños, los consideraba una tabula rasa donde escribir otra identidad, los despojaba hasta dejarlos inermes en su nuda vida" (Basile, 2016, p. 362) ${ }^{3}$.

No capítulo "O mistério dos bebês", a narrativa de Kucinski introduz a questão dessas crianças que o estado ditatorial "desapareceu", tabulas rasas nas quais a violência escreveu novas genealogias, identidades e destinos. A través dos diálogos entre Maria do

\footnotetext{
3 “A chave desta figura está na apropriação pela máquina do terrorismo de Estado, que tirou todos os direitos das crianças, considerou-as uma tabula rasa onde escrever outra identidade, despojou-as até ficarem indefesas na sua пиа vida".
}

Revista Moara, n. 59, ago-dez 2021 ISSN: 0104-0944 
Rosário e Durval, emerge o que permaneceu recalcado na (des)memória da época ditatorial:

Durval, preciso te dizer uma coisa, pode não ser nada, mas pode ser importante... [...] Deixaram mais um bebê no portão. [...] aparece um carro de madrugada, deixa o pobrezinho no chão, buzina um par de vezes e se manda.

- É sempre o mesmo carro?

- Só vi de longe e no escuro, era um furgão. Achei que era o furgão daquele delegado de São José, acusado de chefiar um esquadrão da morte (Kucinski, 2020).

A través dos olhos e da voz de Rosário, se insinua na narrativa a suspeita crescente de que o orfanato seja a base de um tráfico de crianças, deixadas pela polícia do regime no portão do instituto. O que logo a seguir se instila, é o pressentimento de que os bebês sejam filhos de prisioneiras políticas:

Durval apoia a cabeça nas mãos. Medita. Sentada ao seu lado, Maria do Rosário espera em silêncio.

- Rosário, juntando a história desses bebês com a do dominicano, vai ver ele não estava delirando. Disse que no lugar onde estava matam mulher grávida...

- Isso nós sabemos...

- Você não me deixou completar Rosário, matam depois de a mulher dar à luz (Kucinski, 2020).

Como indica Amelinha Teles no seu texto introdutivo ao livro Infância roubada, no qual se focaliza nas mulheres enquanto mães, militantes e vítimas da repressão numa perspectiva de género, "Crianças também nasceram em cativeiro. Lia Cecília foi uma delas. Hoje com 39 anos, nascida em 1974, na região da guerrilha do Araguaia, filha de um guerrilheiro do Araguaia, desaparecido [...] Sobre sua mãe, não há nenhuma informação, mas encontra-se desaparecida desde aquela época” (Teles, 2014, p. 14). O caso de Lia Cecília pode ser considerado, na opinião de Eduardo Reina, como o caso número 1 no Brasil, por ter sido o primeiro em aparecer e por conter todos os elementos que "tipificam o crime de sequestro de bebês na ditadura brasileira" (Reina, 2019). Lia foi levada ao orfanato Lar de Maria, em Belém, em junho de 1974, por militares que "não escolheram, aparentemente, o lugar por acaso. Sabiam que podiam entregar a criança no

Revista Moara, n. 59, ago-dez 2021 ISSN: 0104-0944 
Lar de Maria e contar com algum grau de cumplicidade" (Reina, 2019). Além disso, conforme Reina, "nos arquivos da instituição não há registros [...] de que bebês ou crianças tenham sido entregues no local. Assim como não existe registro da chegada da bebê em 1974".

Na narrativa de Kucinski, é justamente a rede destas cumplicidades que se desvenda diante dos olhos de Rosário e que é progressivamente revelada ao leitor. Rosário descobre o sistema de conivências a través do qual os bebês subtraídos às prisioneiras políticas ingressavam nos orfanatos para ser depois entregues a famílias - neste caso estrangeiras - falsificando os documentos e apagando os rastros do crime de desaparecimento:

- Não é bem falsificação, padre, a certidão é genuína, o que falseiam é a identidade da mãe; é igualzinho uma adoção à brasileira, só que por estrangeiro; declaram que a mulher deu a luz aqui no Brasil, em casa de família, e registram como filho dela; com a certidão de nascimento, pedem ao consulado um aditivo no passaporte e levam o bebê pra Itália como filho próprio.

- É fácil assim?

- Não sei se é fácil, sei que tem muita gente metida nesse cambalacho, escrivão, delegado, despachante, todos de combinação (Kucinski, 2020).

Rosário decide não só tentar impedir que os bebês deixem o país, mas denunciar, com a ajuda da personagem da jornalista Paula Rocha, o inteiro sistema: "Se perigar os italianos pegarem as crianças, eu estouro o esquema todo" (Kucinski, 2020). Esse esquema, como mostra Reina, na ditatura militar brasileira foi realizado com a cumplicidade de inúmeros atores: “Contra a lei, realizou-se a 'legalização' da adoção de bebês e crianças, baseada em infraestrutura integrada por militares e agentes da repressão, médicos, advogados, religiosos, funcionários públicos e de cartórios, de hospitais, de orfanatos e outras instituições envolvidas” (Reina, 2019).

A repressão contra quem ameaçasse revelar esse sistema é tematizada, no romance, em dois momentos: o primeiro é a censura da reportagem que a jornalista Paula tenta publicar no Estadão. A matéria tem por título "Tráfico de crianças em São José", mas só um dos três artigos chegará a ser publicado. O segundo momento em que a 
repressão se desdobra, entretanto, é o mais violento e definitivo, é a prisão, a morte e o desaparecimento do corpo de Rosário.

O segredo que envolve a prática do sequestro dos bebês é mantido a través da censura e da morte, num encobrimento total, que, tanto na ficção como na realidade, chega até os nossos dias. E a dimensão da sua violência se expressa nesta perpetuação no tempo, perpetuação que atinge a sociedade inteira e, mais dolorosamente os afetados. Suas infâncias foram negadas, suas identidades fraturadas: "Ao serem entregues a famílias vinculadas à repressão ou a instituições onde depois foram adotadas de forma ilegal, perderam sua história, sua memória e principalmente, sua identidade" (Reina, 2019). Como reclama Amelinha Teles, refletindo sobre o caso de Lia Cecília: "São situações que não foram devidamente esclarecidas. Cabe ao Estado brasileiro esclarecer esses fatos" (Teles, 2014, p. 14).

Os “desaparecidos vivos” brasileiros emergem na ficção de Kucinski reclamando não somente uma justiça que nunca foi leveda ao cabo, e que, como aponta Teles, cabe ao Estado brasileiro cumprir, mas primeiramente uma escuta, uma possibilidade de resgate do silêncio no que suas histórias sumiram por décadas.

\section{A pátria e a mater: Júlia e a filiação fraturada}

"O estojo foi o começo de tudo" (Kucinski, 2020): um objeto escondido por décadas na casa de família faz com que Júlia descubra, em poucas horas, uma nova história familiar e, contemporaneamente, uma nova história do Brasil. No estojo são conservados papeis relativos à atividade política do pai - uma lista de nomes, depoimentos de presos, documentação sobre torturas e desaparecimentos, e um relatório em inglês sobre crianças sequestradas - de que a filha nunca soube: “Ao terminar, noite alta, Júlia sente que descobriu um outro país - e um outro pai. Nunca imaginou atrocidades dessas no Brasil” (Kucinski, 2020). Junto àqueles documentos, Júlia encontra umas cartas que revelam que ela foi adotada:

O quadro se impõe com a nitidez e a violência de um raio. Ela é filha adotiva. Em pânico, desprende um último papel colado no fundo ferruginoso do estojo. 
É um formulário amarelecido e manchado. Há nele um sinete quase ilegível que Júlia decifra com dificuldade. Sociedade Vicentina de Jacareí - Casa Maternal e Orfanato São Vicente de Paula. [...] Júlia corre ao banheiro e vomita. A cada duas ou três horas, relê as cartas (Kucinski, 2020).

O primeiro choque que Júlia experimenta tem a ver com o segredo que envolveu tanto a história familiar como a história silenciada da violência ditatorial no Brasil. Ela lembra do pai falando baixo ao telefone, esse pai que falava mal da direita e não gostava da polícia, mas que manteve a família longe de tudo o que pudesse representar um perigo. Agora, a descoberta dos documentos confere um novo significado a esses silêncios familiares: "lembranças do pai apressado ou de cenho franzido ao telefone [...] agora ganhavam algum sentido" (Kucinski, 2020). Mas, ao descobrir seu próprio passado individual, a protagonista encontra, contemporaneamente, um país que até aquele momento desconhecia.

A partir da descoberta do estojo, Júlia ingressa num labirinto, que a coloca na encruzilhada entre a (des)memória dos crimes da ditadura, o silêncio familiar e, sobretudo, na encruzilhada entre as identidades fraturadas desses "desaparecidos vivos" que são as crianças roubadas e os "detidos-desaparecidos" pelo regime, como a sua mãe.

Num primeiro momento, Júlia crê ser filha de pai e mãe adotivos, e a inteira arquitetura da sua genealogia familiar vem abaixo:

Júlia se põe a explorar o apartamento, cismada de que em algum lugar há outro estojo ou algum caderno ou documento com os nomes de seus pais biológicos. $[\ldots]$

Júlia sente-se perdida. Contudo, à medida que prossegue na busca e quanto mais frustrante a busca se revela, mais ela se sente animada por um propósito, como se tivesse descoberto um objetivo de vida que vinha lhe faltando.

Também revê valores. Vivera naquele apartamento uma grande mentira. Vinte e seis anos de mentiras. [...] Todos mentindo. Uma verdadeira conspiração. Como foi possível? Boba! De fato, muito boba! Sente que não é mais ela. Todo seu ser tem que se reconstituir (Kucinski, 2020).

Em seu artigo "Testimonianza e genealogia: Marta Dillon, Sebastián Hacher, Julián López”, Emilia Perassi nos proporciona umas pautas fundamentais para entender a trajetória da nossa personagem. Como escreveu Raquel Robles, escritora filha de 
desaparecidos argentinos, em seu romance Pequeños combatientes, "Los huérfanos no son personas sin padres, al menos no son solo eso. Los huérfanos son - somos arqueólogos, investigadores privados, desenterradores de detalles, buscadores de explicaciones" (Perassi, 2017, p. 365). Esta vai ser a nova tarefa de Júlia, que ao se descobrir órfã se transformará em arqueóloga, detective, "desenterradora" e buscadora de uma identidade inteiramente por reconstruir. Ao se reconhecer órfã, Júlia se faz, pela primeira vez "herdeira", no sentido que Massimo Cacciari atribuiu a esta palavra na conexão etimológica e significante entre herança e orfandade. Como explica Perassi:

O filósofo lembra-nos que o latim "heres" (herdeiro) tem a mesma raiz do grego "kheros" (órfão), que significa "deserto, despojado, carente". Pode herdar, então, só quem se descobre orbus, orphanós [...]. Para ser herdeiro é preciso atravessar todo o luto da própria radical carência. Herdeiro, diz Cacciari, será aquele que reconhece em si como fundamental a relação com os próprios pais e tentará expressá-la em toda a sua terrível dificuldade: "Faz-se herdeiro só aquele que se sente abandonado", ou seja, quem, ao descobrir o abandono se colocará em escuta do que "assim foi", para perceber nele "essas vozes, esses símbolos que possamos reconhecer como relações essenciais, constitutivas da trama do nosso próprio ser" (2017, p. 366, tradução nossa).

Só quando Júlia se descobre "no abandono" é que ela pode se colocar em escuta do passado familiar, e depois nacional, quanto mais se sente "perdida", tanto mais "se sente animada por um propósito", por uma nova finalidade vital. Num primeiro momento, a narrativa simboliza esta escavação no passado como uma 'desmontagem' do apartamento, desse lugar da memória familiar que Júlia tanto respeitou e cuidou, e que agora deve ser materialmente revolvido, cada vez com mais raiva:

Da cozinha, passa aos quadros da sala e do hall e aos espelhos dos banheiros. Desmonta as molduras, revolve a terra dos vasos de plantas na varanda. Nada. Passa a semana sem ir ao trabalho, sondando paredes e soalhos do apartamento com o cabo da vassoura, em busca de algum oco. De início, com cuidado para não estragar a pintura, depois socando forte, raivosamente, até mesmo as paredes recém restauradas. 
Do espaço que até aquele momento tinha representado o cerne de uma individualidade apoiada numa memória estável - após a morte do pai Júlia se tornara uma “zeladora de memórias" paternas, não quis vender o apartamento e conservou todos os objetos do pai -, a casa se transforma em uma cena de escombros e ruinas. É preciso desmontá-la, quebrar suas paredes, empreender uma tarefa de arqueóloga e ao mesmo tempo de destruidora. Como faz notar Thamires Aragão no seu trabalho sobre rastos e escombros em Júlia, com base nas reflexões de Jeanne Marie Gagnebin, "Sobre os destroços de uma narrativa incompleta, muitas vezes alterada ou surrupiada, a protagonista precisou procurar vestígios e arquitetar pistas. Encontramos no romance a tentativa de recuperar algo em meio às ruínas" (Aragão, 2021, p. 160). No romance, a protagonista deverá empreender uma luta "contra as lacunas", buscar "nos farelos do tempo a chance de recuperar a sua própria identidade” (Aragão, 2021, p. 161). Poderíamos dizer que a imagem da casa destroçada remete justamente para esta passagem, de uma memória estável e passível de ser cuidada, para uma paisagem de escombros que simboliza a verdadeira herança de Júlia, pois, "a protagonista tem na ruína a sua principal herança familiar" (Aragão, 2021, p. 161). A tarefa de Júlia será então a de (re)construir sua própria herança a partir de dois elementos totalmente novos e chocantes: a ruina e a orfandade.

E aqui, no entanto, o romance de Kucinski é capaz de introduzir na trama do texto uma extrema complexidade. Num primeiro momento a protagonista enfrenta a desconstrução absoluta da própria identidade: "Se não é filha do seu pai engenheiro Durval dos Santos Lima e da sua mãe Margarida dos Santos Lima, quem é ela? De onde veio? Quem eram seus pais biológicos? E por que as cartas da tia Hortência e os papéis de adoção estavam junto com histórias de atrocidades dos tempos da ditadura?" (Kucinski, 2020). Mas no final do romance Júlia descobrirá ser só parcialmente filha adotiva, pois o pai biológico a adotou de acordo com Maria do Rosário:

\footnotetext{
A Rosário engravidou de caso pensado, queria ter um filho do teu pai, mas na situação de militância dela era perigoso, podiam chantagear, não vou nem te contar o que faziam. Teu pai então acertou com a Rosário que se acontecesse o pior ele levaria a criança para São Paulo como se fosse adotada. Deixaram tudo preparado, para simular a adoção. [...]
} 
No que ela foi presa, teu pai pôs em prática o estratagema da adoção (Kucinski, 2020).

Graças aos testemunhos das personagens que na época colaboraram com a militância - a jornalista Paula Rocha e o Magno - Júlia compreende que o grande vazio a preencher para reconstruir a memória familiar, e a sua identidade, é representado pelo desaparecimento da mãe. E, no descobrimento improviso desta ausência materna, se mostram em toda sua crueldade a violência da repressão e a ausência de uma justiça de transição. Neste sentido, ao descobrir os segredos da família, Julia encarrega-se de um trabalho de busca que tem a ver com dois elementos fundamentais: a pátria, o Brasil, e a mater, isto é, a sua filiação materna. "Agora me conte, me conte tudo; tudo, tudo, tudo. Como foi que minha mãe foi presa? O que aconteceu depois? Como ela foi morta? Quero saber tudo", diz Júlia à jornalista Paula. E Paula responde: “É difícil falar essas coisas, é difícil até de acreditar... Eles arrancavam tudo o que podiam dos presos, os nomes, os endereços, depois matavam e sumiam com os corpos. A Maria do Rosário foi pega nessa época, na pior época” (Kucinski, 2020).

A orfandade que agora Júlia assume é uma "orfandade suspendida", como a definiria Teresa Basile, a que atinge os filhos que "en principio no cuentan con la muerte de los padres sino con su desaparición, y como sabemos esta particular condición se caracteriza por la indefinición, el desborde de los conceptos identitário acuñados, la impertinencia (no pertenencia) categorial" (Basile, 2016, p. 142). E os interrogativos que se desprendem desta condição têm a ver, no caso do Júlia, tanto com o apagamento dos documentos e com o ensurdecedor silêncio institucional brasileiro - "Como é que na escola nunca falaram dessas barbaridades?" -, mas também com a necessidade de conhecer o destino da mãe: “Nunca se descobriu nada?", pergunta Júlia, e Paula responde: “O Magno conseguiu descobrir que ela foi morta numa penitenciária do interior. Isso é quase certo porque os dados da mulher que lá foi morta e de quem prendeu conferem" (Kucinski, 2020).

A este silêncio da história, à "quase certeza da morte", responde a narrativa, no capítulo titulado "Na sucursal do inferno", em que o leitor entra nas salas da penitenciária

\footnotetext{
4 “[...] em princípio, não contam com a morte dos pais, mas com o seu desaparecimento, e como sabemos esta condição particular é caracterizada pela imprecisão, pelo transbordamento dos conceitos de identidade cunhados, pela impertinência (não pertencimento) categorial".
} 
na qual é posta em cena - embora só sugerida e nunca plenamente 'testemunhada' - a morte de Rosário. Entre os murmúrios dos presos e as batidas nas grades, que eles fazem "para impedir que o preso seja morto", o destino da prisioneira é narrado a través dos olhos do agente penitenciário Juruna. Ele conseguiu ver uma mulher bonita, de uns vinte anos, que "apanhou demais": "As pupilas negras envoltas em sangue e o rosto e os braços cobertos de hematomas. A blusa rasgada deixava à mostra os seios. Adivinha, transtornado, o que estão fazendo com a moça no fundão, e sente-se mal" (Kucinski, 2020).

Analisando a repressão contra mulheres na ditadura numa perspectiva de género, Amelinha Teles nos lembra que

\footnotetext{
Com o desenvolvimento da luta contra a ditadura, a participação das mulheres tornou-se mais incômoda para a repressão que usou de métodos os mais perversos, reforçando o moralismo e preconceito machistas para desmoralizar a participação das mulheres. Na tortura, as militantes eram tratadas pelos policiais, de um modo geral, como putas, amantes, amasiadas e justificavam assim os estupros nas dependências dos DOI-CODIs (Teles, 2014, p. 20).
}

Em quanto mulher, como todas as mulheres militantes, Maria do Rosário subverte "a ordem patriarcal tão solidamente acomodada na ideologia do regime" (Teles, 2014, p. 20) e por isso ela é vítima de uma dúplice forma de violência: a violência repressora e a violência machista. Mas, em quanto mulher, Rosário padece também a violência da separação da sua filha, da cisão da relação maternal com uma filha que será condenada a desconhecer sua identidade, seu destino, e nunca poderá prestar homenagem ao seu corpo. É a narrativa que compensa, pelo menos parcialmente, esses interrogativos, restituindo, numa cena coral, o momento da morte da mulher: "O pavilhão está mergulhado em desespero coletivo. Faz-se um silêncio de morte. Assim transcorrem cinco, dez minutos. [...] Súbito, o grito de dor vindo do fundão. Um grito único, longo e cortante. E o pavilhão explode" (Kucinski, 2020). Mais informações vem das testemunhas com que Júlia conversa, como a própria Paula: "O que nos disseram é que a tua mãe teria sido levada a um sítio clandestino [...] Isso do presídio é certo, teve gente que viu. Lá mataram a tua mãe. O próprio Felipe matou. Depois sumiram com o corpo” (Kucinski, 2020). 
Se em K. Relato de uma busca, o protagonista, logo no começo do romance, adquiria uma nova identidade, passando a exercer o papel de familiar de uma (filha) desaparecida, no caso de Júlia, esta transformação, às avessas, acontece no final do romance, quando ela toma consciência da dimensão trágica do desaparecimento da mãe e assume um novo papel, juntando-se ao destino desses órfãos "em suspenso" que são os filhos dos desaparecidos:

\begin{abstract}
Júlia consegue os telefones da Secretaria Nacional dos Direitos Humanos e do grupo Tortura Nunca Mais. Indaga se Maria do Rosário consta de alguma lista de mortos e desaparecidos políticos. Dizem que não. Pergunta se estavam montando algum banco de DNA, para identificar despojos quando fossem localizados. Dizem que sim. - Eu quero registrar o desaparecimento de minha mãe, Maria do Rosário, doar meu DNA para esse banco de dados, como é que eu faço? (Kucinski, 2020).
\end{abstract}

É o começo de uma nova busca, de uma reconstrução identitária que passa pela reconstituição (im)possível dos pedaços de uma filiação materna interrompida, essa "família rota" da que fala Félix Bruzzone (Basile, 2016, p. 143). Uma tarefa "penosa", reflexiona o narrador omnisciente: "Em vez de encontrar a mãe, encontrou uma tragédia, que também era sua, que passava a ser sua. Uma tragédia atravessando três gerações" (Kucinski, 2020).

É talvez nesta encruzilhada de "três gerações" que o romance atinge seu maior grau de complexidade, porque é neste ponto que a protagonista consegue reenlaçar os fios dessa linha matrilinear fraturada. Com estilemas que lembram de perto os contos de fadas, Kucinski faz aparecer ao longo da narrativa a personagem de uma anciã, uma velhinha "de pano preto com bolinhas brancas", que muitos anos antes tinha perdido uma menina, entregue ao orfanato de São Vicente de Paula e desde então desaparecida. Ao longo de sua busca, e por sua grande surpresa, Júlia topa com a velhinha na Igreja Matriz de São José, ela "surge do nada e menciona o orfanato no qual ela foi adotada". A história que a mulher conta é a história de uma violência transgeracional: essa mulher pobre, "violada pelo patrãozinho", obrigada a abandonar sua bebê no orfanato, não sabe que sua criança cresceu no mesmo lugar, se tornou militante, teve uma filha, e foi morta pelo regime. Não sabe que sua filha era Maria do Rosário. 
Com este expediente literário, a mãe desaparecida de Júlia vem a representar, quase numa mise en abyme, esses "desaparecidos vivos" que são as crianças sequestradas, subtraídas às mães solteiras muito antes de a ditadura estourar. As mesmas crianças pelas quais Rosário se imolará na sua luta contra o regime, perdendo, assim, sua própria bebê:

\footnotetext{
A velha que vai todo sábado se lamentar na matriz de São José é sua avó, a avó que nunca teve. Ia se apresentar como sua neta. Ia dizer que a filhinha por quem chorava nunca foi levada à Itália. Ia dizer que sua filhinha tornara-se uma mulher bonita e boa e teve vida curta, mas intensa. Ia pedir uma amostra de seu sangue para o banco de DNA. Não. Isso não era necessário (Kucinski, 2020).
}

Esta mise en abyme aponta também para o abismo da história violenta do Brasil, pois Kucinski reconstrói uma concatenação de violências que tem origens longínquas e patriarcais - o "tempo que tinha barão" - e que se exerce nos corpos das crianças e das mulheres, prejudicando genealogias familiares e às próprias origens da nação.

Quase evocando o papel salvífico e tenaz das Abuelas de Plaza de Mayo, o romance se conclui com esta, única, possibilidade de recomposição identitária, pela via materna, que Júlia obtém, às avessas, como resultado da sua busca. Uma busca individual, levada ao cabo não obstante as omissões e a violência mnemónica que, ainda hoje, o silêncio institucional impõe.

\section{REFERÊNCIAS}

ARAGÃO, Thamires. Rastros e escombros em "Júlia: nos campos conflagrados do senhor", de Bernardo Kucinski. EntreLetras, vol. 12, n. 2, p. 156-166, 2021.

ARFUCH, Leonor. Narrativas en el país de la infancia. Alea, Estudos Neolatinos, vol. 18, p. 544-560, 2016.

BASILE, Teresa. La orfandad suspendida: la narrativa de Félix Bruzzone. Revista del CELEHIS, vol. 25, n. 32, 2016, p. 141-169, 2016.

BASILE, Teresa. Infancias. La narrativa argentina de HIJOS. Villa María: Eduvim, 2019. 
BRUM, Liniane Haag. Antes do passado: o silêncio que vem do Araguaia. Porto Alegre: Arquipélago Editorial, 2012.

FIGUEIREDO, Eurídice. A literatura como arquivo da dtadura brasileira. Rio de Janeiro: 7Letras, 2017.

FUKS, Julián. A resistência. São Paulo: Companhia das Letras, 2015.

GILL DA CRUZ, Lua. Pretéritos futuros: ditadura militar na literatura do século XXI. Tese de Doutorado. Universidade Estadual de Campinas, SP, 2021.

GRAMMONT, Guiomar De. Palavras Cruzadas. Rio de Janeiro: Editora Rocco, 2015. KUCINSKI, Bernardo. K. Relato de uma busca. São Paulo: Expressão Popular, 2011. KUCINSKI, Bernardo. Júlia. Nos campos conflagrados do Senhor. São Paulo: Alameda, 2020. Edição digital.

LEVY, Tatiana Salem. A chave de casa. Rio de Janeiro: BestBolso, 2013.

PAIVA, Marcelo Rubens. Ainda estou aqui. Rio de Janeiro: Alfaguara, 2015.

PERASSI, Emilia. Testimonianza e genealogia: Marta Dillon, Sebastián Hacher, Julián López. In: Perassi E.; Scarabelli, L. (Org.). Letteratura di testimonianza in America Latina. Sesto S. Giovanni: Mimesis, 2017, p. 365-385.

REINA, Eduardo. Cativeiro sem fim. As histórias dos bebês, crianças e adolescentes sequestrados pela ditadura militar no Brasil. São Paulo: Alameda. 2019. Edição digital.

REINA, Eduardo. Depois da Rua Tutóia. Jaú, SP: 11 Editora, 2016.

SECRETARIA ESPECIAL DOS DIREITOS HUMANOS DA PRESIDÊNCIA DA REPÚBLICA. Direito à memória e à verdade. Histórias de meninos e meninas marcados pela ditadura. Brasília: Secretaria Especial dos Direitos Humanos, 2009.

Disponivel

em:

http://www.mpgo.mp.br/portalweb/hp/41/docs/direito_a_memoria_e_a_verdade__historia_de_meninos_e_meninas_marcados_pela_ditadura.pdf Acesso em: 22/12/2021. SILVEIRA-BAUER, Caroline. Um estudo comparativo das práticas de desaparecimento nas ditaduras civil-militares argentina e brasileira e a elaboração de políticas de memória em ambos os países. Tese de Doutorado. Universidade Federal do Rio Grande do Sul; Departament d'Història Contemporània da Universitat de Barcelona. Porto Alegre; Barcelona, 2011. 
TELES, Amelinha. Introdução. In: ASSEMBLEIA LEGISLATIVA DE SÃo PAULO; COMISSÃO DA VERDADE DO ESTADO DE SÃO PAULO "RUBENS PAIVA". Infância Roubada. Crianças atingidas pela Ditadura Militar no Brasil. São Paulo: ALESP, 2014. p. 13-20. Disponível em: http://www.mpsp.mp.br/portal/page/portal/documentacao_e_divulgacao/doc_biblioteca/ bibli_servicos_produtos/BibliotecaDigital/BibDigitalLivros/TodosOsLivros/Infanciaroubada.pdf Acesso em: 22/12/2021.

TELES, Edson; SAFATLE V. O que resta da ditadura: a exceção brasileira. São Paulo: Boitempo Editorial, 2015.

TERRON, Joca Reiners. Noite dentro da noite: uma autobiografia. São Paulo: Companhia Das Letras, 2017.

VECCHI, Roberto. Desaparição política e ditadura militar no Brasil: a literatura como ato de restituição. In: BELLO VÁZQUEZ, R.; TORRES FEIJÓ, E. (Org.). Estudos da AIL em Literatura, História e Cultura Brasileiras. Santiago de Compostela; Coimbra: AIL Editora. 2015, p. 151-156.

UNIVESP TV. Livros 141: Depois da rua Tutóia - Eduardo Reina. Disponível em: https://www.youtube.com/watch?v=SN_LNyLz7gw Acesso em: 22/12/2021.

VIDAL, Paloma. Mar azul, Rio De Janeiro: Rocco, 2012. 